\title{
Study on the Influence of Free Radicals and Oxidative Stress on Peptic Ulcers
}

\begin{abstract}
GERMAINE SAVO IU BALINT ${ }^{1 *}$, EMERIC TOTH ${ }^{2 *}$, MIHAIELA ANDONI ${ }^{1 *}$, IOAN DEMETER ${ }^{2 *}$, CLAUDIA BORZA ${ }^{2}$, ERWIN FLORONI ${ }^{2}$, MARIANA PACURAR ${ }^{3}$, VIRGIL CIOBANU²

'University of Medicine and Pharmacy Victor Babes Timisoara, Faculty of Pharmacy, 2 Eftimie Murgu Sq., 300041, Timisoara, Romania

${ }^{2}$ University of Medicine and Pharmacy Victor Babes Timiooara, Faculty of Medicine, 2 Eftimie Murgu Sq., 300041, Timisoara, Romania

${ }^{3}$ University of Medicine and Pharmacy Targu Mures, Faculty of Dentistry, 38 Gh. Marinescu Str., 540072, Targu Mures, Romania

It can be observed that oxidative stress initiates and aggravates many diseases, including peptic ulcers and gastric carcinoma. An increase in rat mucosal glandular lipid peroxidation (LPO) and superoxide dismutase (SOD) and a decrease in catalase (CAT) levels in gastric ulceration induced by cold retention stress were observed, whereas in patients with ulcerated clinical peptic and gastric carcinoma $L P O$ serum is associated with a decrease in SOD and CAT. It was intended to determine the parameters of oxidative stress in the blood and brain in rats after induction of gastric ulcer, the effect of antioxidant treatmenton these parameters and on the appearance of gastric ulcer, determination of correlation between oxidative stress and severity of gastric ulcer in rats and also evaluation of vascular endothelial function by in vitro studies in the organ bath, from rat aortic rings with gastric ulcer vs. normal and others under treatment vs. untreated.
\end{abstract}

Keywords: oxidative stress, gastric ulcer, reactive oxygen species, reactive nitrogen species

Gastric ulcer is pathology with a varied etiology, incomplete elucidated that is characterized anatomically by mucosal damage to the stomach and the presence of a wound, and is also surrounded by an acute or chronic inflammatory component. The damage to the gastric mucosa is visible through the intensity of the lesion and its depth, thus reaching the advanced stage when the gastric mucosa is deeply perforated and giving birth to peritonitis [1].

Risk factors for ulcer disease are multiple, including: the presence of Helicobacter Pylori bacteria, caffeine, genetic factors, diet, and abuse of anti-inflammatory and analgesic substances, Zollinger-Ellison Syndrome [2] .

The human body is able to defend itself naturally, so that the perfectly healthy gastric mucosa subjected and permanently exposed to various stress factors has the ability to maintain the functional and structural intestinal lining of the stomach.

At the stomach, there are natural mechanisms of protection and protection of the gastric mucosa that neutralize gastric acid and the action of pepsin; for example: superficial mucosal cells, prostaglandins, which in turn increase the amount of bicarbonate and protective mucus. These protective mechanisms often fail to cope and gastric ulcer occurs [3].

There are many and various aggressive factors that trigger this imbalance, having different or even common mechanisms, including oxygen radicals, which occur during normal cellular respiration, a normal physiological process. In the body there must be a balance between reactive oxygen species and antioxidants to avoid oxidative stress [4].

Another important factor involved in ulcer disease is the mental stress that intensely stimulates the sympathetic and parasympathetic nervous system, producing vasoconstriction with the stimulation of motor activity and smooth muscle cramps, sometimes even local ischemia. Processes occur in the chain, therefore hypoxia stimulates the production of reactive oxygen species and the occurrence of the harmful effects presented above [5].

In this study it was intended to determine the parameters of oxidative stress in the blood and brain in rats after induction of gastric ulcer, the effect of antioxidant treatment on these parameters and on the appearance of gastric ulcer, determination of correlation between oxidative stress and severity of gastric ulcer in rats and also evaluation of vascular endothelial function by in vitro studies in the organ bath, from rat aortic rings with gastric ulcer vs. normal and others under treatment vs. untreated [6].

\section{Experimental part \\ Animals used}

In the present study, Wishstar rats ( $n=9,250-350 \mathrm{~g}$, adults) were used. The experiments were conducted according to the regulations approved by the NIAH (National Institute for Animal Health) and Directive 2010/ 63/ EU. These were conducted with the permission of the Animal Expert Ethics Commission of the University of Medicine and Pharmacy of Timisoara. The animals were kept under classical controlled conditions with a light and dark interval of 11 hours, food and water at will at unchanged temperature $\left(22 \pm 2^{\circ} \mathrm{C}\right)$.

The animals used were divided into three classes: a control group (control: $n=3$ ) on which the UG induction procedure was not performed and an untreated group on which a gastric ulcer induction protocol $(n=3)$ a group on which a gastric ulcer production protocol was performed $(n=3)$ [7-10].

\section{Treatment used}

To achieve the objectives of this study, part of the rats were treated with an antioxidant: antioxidant complex (SC Alevia SRL). Composition: Coenzyme Q10 5mg, Ginko biloba 20mg, Green tea $20 \mathrm{mg}$, Blueberry $20 \mathrm{mg}$, Grape spit 40 mg, Vitamin E 20 mg, Vitamin A 2500 U.I .

\footnotetext{
*email: andoni.mihaiela@umft.ro; demeter.ioan@gmail.com,Phone: 0040722608086,0722564003 \#Authors with equal contribution 


\section{Gastric ulcer induction protocol in rats}

The method of inducing gastric ulcer in rats was to limit mice for several days in a very small cage (there the animals were able to perform small activities) for a period of 60 minutes, preceded by another 60 minutes of total snapping, by closing the mice in small bags (with a hole in the airway for breathing) [11-13].

After the 10 days the animals were anesthetized (ketamine $5 \mathrm{mg} / \mathrm{kg}$ and xylazine $30 \mathrm{mg} / \mathrm{kg}$ ) and sacrificed by cervical dislocation. After the surgical opening of the abdominal cavity, the stomach was removed and placed in an ice bath $\left(40^{\circ} \mathrm{C}\right)$. Longitudinal splitting was performed on the large stomach curve.

\section{Determination of superoxide dismutase in blood}

The SOD measurement was performed following the procedure of Sun et al. (34). This was based on the determination of $\mathrm{Cu}, \mathrm{ZnSOD}$ in the blood collected from animals before they were anesthetized and killed. The method is based on the reduction of the blue solution of nitrotetrazolium with xanthine-xanthine oxidase and the spectrophotometric determination of the formazan production at $560 \mathrm{~nm}$ and implicitly the calculation of the SOD activity [14-16].

The total of the reactive chemical reagents were purchased from Sigma Aldrich Company.

\section{Determination of catalase in blood}

The determination of catalase action was performed by the procedure of Ronald et al. (2) which consisted in determining the spectrophotometer for the separation of peroxide by the catalase

\section{Determination of superoxide dismutase in brain}

To measure SOD activity in the brain, we used $5 \%$ cytosol ( $50 \mathrm{mg}$ brain tissue in $1 \mathrm{~mL} 0.1 \mathrm{M}$ phosphate buffer $\mathrm{pH} 7.4$ and centrifuged under cooling at 20-30 thousand r.p.m for 30 minutes). Then we performed the activity in two copies using 5-10 microliters of cytosol prepared previously [17].

\section{Determination of catalase in brain}

To measure CAT activities, we used $5 \%$ cytosol $(50 \mathrm{mg}$ brain tissue in $1 \mathrm{~mL} 0.1 \mathrm{M}$ phosphate buffer $\mathrm{pH} 7.4$ and centrifuged under cooling at 20-30 thousand r.p.m for 30 $\mathrm{min})$. Then, duplicate activity was performed using 5-10 microliters of cytosol prepared previously [18].

\section{Evaluation of vascular reactivity in the organ bath}

For the study of vascular reactivity in this project we used protocols to assess the contractility and relaxation of rat vascular rings in the isolated organ bath. Experiments were performed in the presence of diclofenac $(10 \mu \mathrm{mol} /$ $\mathrm{L})$. The concentration of phenylephrine used to cause preconstriction was adjusted to obtain $80 \%$ of the $\mathrm{KCl}(80$ $\mathrm{mmol} / \mathrm{L}$ ) contractile effect. Later, endothelial-dependent cumulative acetylcholine-dependent relaxation was recorded in the presence or absence of various MAO inhibitors (chlorgillin, moclobemide, deprenyl-10 $\mu \mathrm{mol} / \mathrm{L}$ ) [19-20].

\section{Results and discussions}

Before we sacrificed the animals we took blood to determine SOD and catalase. After animal sacrifice we followed the macroscopic evaluation of gastric-induced lesions (Figure 1), as well as the determination of SOD and catalase from the lysis of the brain.

In order to evaluate the vascular reactivity, after sacrificing the animals we took fragments from the

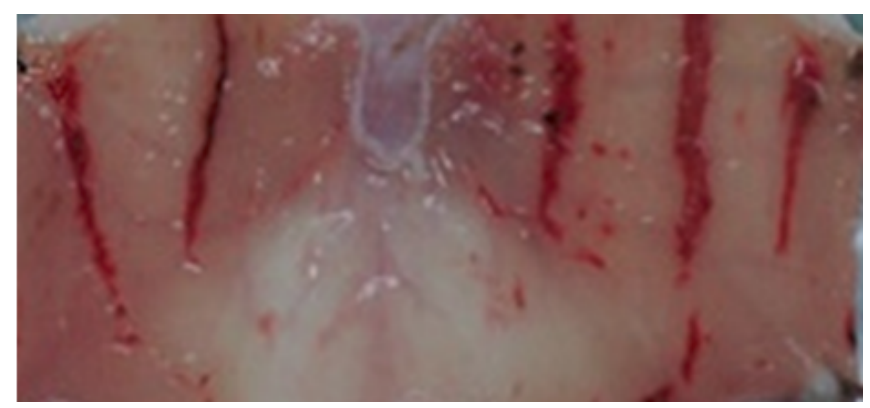

Fig.1. Representative image of gastric ulcer induced in the group of untreated rats

Table 1

AVERAGE \pm STANDARD DEVIATION OF SOD AND CATALASE OBTAINED IN THE STUDIED GROUPS

\begin{tabular}{|c|c|c|c|}
\hline & Control & UG - AOX & UG + AOX \\
\hline SOD blood (U/mg) & $6.52 \pm 1.07$ & $3.15 \pm 1.20$ & $4.03 \pm 0.95$ \\
\hline SOD brain & $5.20 \pm 0.40$ & $6.86 \pm 0.75$ & $7.43 \pm 0.17$ \\
\hline Catalase blood (U/mg) & $9.77 \pm 1.50$ & $8.57 \pm 0.85$ & $9.15 \pm 0.81$ \\
\hline Catalase brain & $3.10 \pm 0.21$ & $4.71 \pm 0.38$ & $4.93 \pm 0.28$ \\
\hline
\end{tabular}

abdominal aorta, which were subsequently segmented in $0.25-1 \mathrm{~cm}$ vascular rings. These rings were placed in the organ bath (10 mL volume) in a Biopac MP 100 plant (BIOPAC System Inc, USA) and were fastened using a stainless steel wire grip system. Twelve vascular rings were introduced, on which reactivity was studied; studies have been carried out according to the Helsinki Declaration and the corresponding ethical principles.

The isometric tension produced by the abdominal aortic rings was measured continuously using a FORT 10 isometric force transducer. The results obtained were processed using a BIOPAC AcqKnowledge software version 3.7.2 (BIOPAC System Inc.USA).

Vascular arterial abdominal preparations were preloaded to $1.5 \mathrm{~g}$ of force and calibrated for $60 \mathrm{~min}$, with a change of Krebs-Henseleit solution over a 15 min interval; solution introduced throughout the experiment to preserve the viability of the vascular preparations. This solution was thermostated at 37 degrees $C$, and continuously aerated with carbogenic mixture $\left(95 \mathrm{O}_{2}+5 \mathrm{CO}_{2}\right)$ and at a constant $\mathrm{pH}$ of 7.4. During the experiment, any contact with the luminal surface was avoided in order to secure the integrity of the gastric endothelium.

Two identical results were observed for $\mathrm{KCl} 70 \mathrm{mmol} / \mathrm{L}$. and 1 vasodilation result at 10-5 M ACh over 10-15\% of the developed $\mathrm{KCl} 70 \mathrm{mmol} / \mathrm{L}$ in order to test the viability of the preparation. The preparation was followed by the appearance of two identical shrinkage results at $\mathrm{KCl} 70$ and a vasodilator response at $\mathrm{ACh} 10^{-5} \mathrm{M}$ greater than 10 $15 \%$ of the $70 \mathrm{kD}$ developed $\mathrm{KCl}$ tension. in order to test the viability of the preparation, and preincubated for half an hour with Indometacin $\left(10^{-5} \mathrm{M}\right)$ for the inhibition of cyclooxygenase and the synthesis of products derived from arachidonic acid.

The test involved finding the result of endothelial vasodilation - subjected to multiple doses of $5^{1}-A D P\left(10^{-9} \mathrm{M}\right.$ $-10^{-4} \mathrm{M}$ ) and endothelial vasodilatation outcome - multiple dose NPS $\left(10^{-9} \mathrm{M}-10^{-4} \mathrm{M}\right)$ on the content of a $10^{-5} \mathrm{M}$ PHEinduced precontract before and after the oxidized lipoproteins are preincubated (ox-LDL), i.e., the incubation with oxidized lipoproteins (ox-LDL $+V E$ ). The results of 
the reactivity changes were compared with the preincubation results with $1 \%$ PBS solution.

The results obtained are presented in figure 2 and 3.

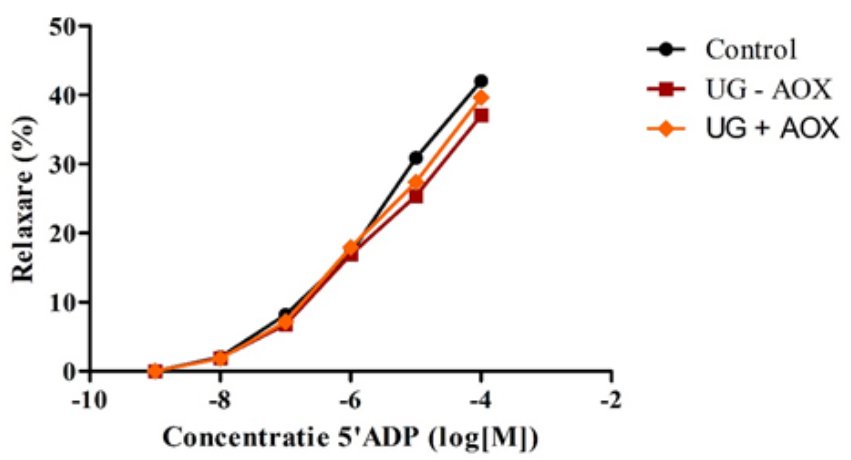

Fig. 2 Endothelial-dependent relaxation obtained at 5'-ADP for all studied groups

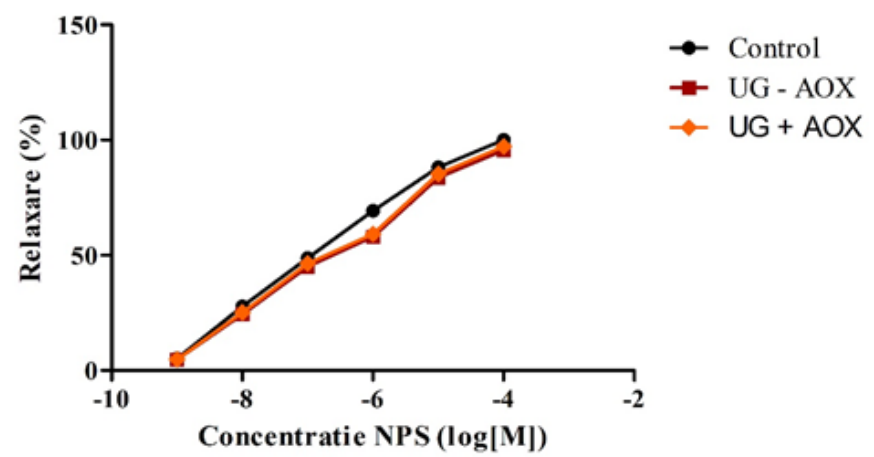

Fig. 3 Endothelial-independent relaxation obtained at NPS for all studied groups

By statistical processing of the data we did not notice significant changes in vascular reactivity at 5'ADP and NPS, for UG-AOX and UG + AOX vs. Control.

In this study we demonstrate that Superoxide dismutase is a marker of oxidative stress because the amount of SOD has decreased in oxidative stress and its antioxidant capacity without association of antioxidant therapy has caused gastric lesions.

The genesis of oxidative stress-induced gastric lesions is a multifactorial process that begins mainly with the depletion of gastric wall mucosal contents. Such depletion is often associated with significant free radical production, causing damage to the cell and cell membrane due to excessive oxidative stress. Generation of reactive oxygen species (ROS), for example, superoxide anion, hydrogen peroxide and hydroxyl radicals, can cause lipid peroxidation, especially in the membrane, and results in tissue damage. High levels of lipid peroxidation have been observed in animals with induced ulcers. For this reason, presence of MDA levels indicates tissue damage due to damage to antioxidant activities to cope with oxidative stress and free radical manipulation. How ever, ithas been reported that the first line of defense against oxidative damage caused by lesions such as ulcers involves the migration of free radical cleansing enzymes such as SOD, CAT and GPX to remove first, $\mathrm{O}_{2}$ and $\mathrm{H}_{2} \mathrm{O}_{2}$ before the formation of harmful hydroxyl $\left(\mathrm{OH}^{2}\right)$ radical.

The presentstudy and others in the literature have shown that antioxidant treatmenthas led to a significant decrease in plasma carbonylated protein (CAT) values, but this change was notmet in the case of malondialdehyde (MDA). These changes probably occurred as a result of the oxidative mechanism of action deployed, mainly found to stimulate protein oxidation in comparison with the membrane lipid oxidation capacity. Atthe same time there are studies that support and demonstrate the importance of the involvement of membrane lipid peroxidation in the case of duodenal ulcer and less in the case of gastric ulcer.

The current study has shown that there have been significant increases in lipid peroxidation (MDA) and a reduction in GSH, GPX, SOD and catalase in the untreated ulcer group compared to the normal control group. This observation may highlight the role of oxidative damage and the induction, development and / or maintenance of the ulcer. Data showed that oral administration of manuka and ranitidine honey interfered with the oxidation process by reducing free radicals (MDA) and increased levels of GSH, GPX, SOD and catalase. These data suggest that manuka honey increases GPx activity to form GSH and increases the elimination of reactive metabolites along with GSH.

\section{Conclusions}

This study demonstrated antioxidant therapy possessing a strong protective activity on the gastric mucosa, which results in a reduction in lipid peroxidation and a decrease in the inflammatory process.

The current study therefore adds to the long list of health benefits that are associated with the consumption of highpotency antioxidant foods that promote better health.

Improvement of oxidative stress parameters was more significant in the case of mice treated with antioxidant therapy.

Based on this study, we could say that markers of oxidative stress with a role in the pathogenesis of gastric ulcer may be considered: superoxide dismutase, monodialdehyde and carbonylated proteins.

\section{References}

1.PANDA V., SONKAMBLE M. Functional Foods In Health And Disease,

2, no.3, 2012, p. 48

2. ANDONI, M., IOVI, A., NEGREA, P., NEGREA, A., CIOPEC, M., Rev. Chim. (Bucharest), 59, no. 6, 2008, p. 653

3. ANDONI M., IOVI, A., NEGREA, P., LUPA L., NEGREA, A., CIOPEC, M., Rev. Chim. (Bucharest), 59, no. 7, 2008, p.779

4. ANDONI, M., DRAGOMIRESCU, A., URSOIU, I., IOVI A., NEGREA P., LUPA L., NEGREA, A., CIOPEC, M., Rev. Chim. (Bucharest), 60, no.4, 2009, p.424

5.POP, R ILICI, M ., ANDONI, M., BERCEAN, V.N., MUNTEAN, C., VENTER, M.M., JULEAN, I., Acta Chimica Slovenica, 62, no.1, 2015, p.8

6. SIMU, G-M., CORICOVAC, D., CSEH, L., SOICA, C., BORCAN, F., IONESCU, D., ANDONI, M., DRAGOS, D., DEHELEAN, C., Rev. Chim. (Bucharest), 67, no. 2, 2016, p. 291

7. ANDONI, M., POP, R., SOICA, C., SIMU, G-M., ILICI, M., ARDELEAN, S., ONISEI, D., DEHELEAN, C., Rev. Chim. (Bucharest), 66, no. 5, 2015, p. 637

8. ANDONI, M., MEDELEANU, M., STEFANUT, M., CATA, A., IENASCU, I., TANASIE, C., POP, R., J. Serb. Chem. Soc. , 81, no.2, 2016, p. 177

9. SUTA, L.M., VLASE, G., VLASE,T., SAVOIU-BALINT, G., OLARIU, T., BELU, I., LEDETI, A., MURARIU, M.S., STELEA, L., LEDETI, I., Rev. Chim. (Bucharest), 67, no. 1, 2016, p. 84

10. BORUGA, O., SAVOIU, G., HOGEA, E., HEGHES, A., LAZUREANU, E.V., Rev. Chim. (Bucharest), 66, no. 10, 2015, p. 1651

11. SUTA, L.M., VLASE, G., VLASE,T., OLARIU, T., LEDETI, I., BELU, I., IVAN, C., SARAU, C.A., SAVOIU-BALINT, G., STELEA, L., LEDETI, A., Rev. Chim. (Bucharest), 67, no. 1, 2016, p. 113

12.SAVOIU-BALINT, G., PETRUS, A., MIHAESCU, R., IONESCU, D., CITU, C., MARINCU, I., TOMA,C.C., Rev. Chim. (Bucharest), 66, no. 6, 2015, p. 833

13. LEDETI, I., SIMU, G., VLASE, G., VLASE, T., OLARIU, T., SAVOIU, G., SUTA, L.M., POPOIU, C., FULIAS, A., Rev. Chim. (Bucharest), 65, no. 5, 2014, p. 556 
14.OLARIU, T., SUTA, L.M., POPOIU, C., LEDETI, I.V., SIMU, G.M., SAVOIU-BALINT, G., FULIAS, A., Rev. Chim. (Bucharest), 65, no. 6, 2014, p.633

15.SIMU, G.M., LEDETI, I.V., MUNTEAN, S.G., FULIAS, A., CITU, I.M., SOICA, C., ONISEI, D., SAVOIU-BALINT, G., PANZARU, I., IONESCU, D., Rev. Chim. (Bucharest), 65, no. 6, 2014, p.644

16.BORZA, C., NEGHINA, A.M., DUMITRASCU, V., TIRNEA, L., CALMA, C.L., NEGHINA, R., VECTOR-BORNE AND ZOONOTIC DISEASES, 12, no.8, 2012, p. 712

17. SAVOIU BALINT, G., BORZA, C., CRISTESCU, C., ANDONI, M., SIMU, G.M., MALITA, D., MALITA, I., CHEVERESAN, A., Rev. Chim. (Bucharest), 62, no. 6, 2011, p.680
18. BORZA, C., OANCEA, C., MATEESCU, R., SAVOIU-BALINT, G., CRISTECU, C., ANDONI, M., SIMU, G.M., BUTUTR, M., DEHELEAN, C., PAUNCU, E.A., JFAE, 9, no.1, 2011, p. 175

19. SAVOIU, G., CRISTESCU, C., SERBAN, C., NOVEANU, L., BORZA, C., DEHELEAN, C., ANDONI, M., ANDOR, M., FIRA-MLADINESCU, O., REVISTA ROMANA DE MEDICINA DE LABORATOR, 18, no.4, 2010, p. 25

20. BHATTACHARYYA, A., CHATTOPADHYAY, R., MITRA, S., CROWE, S.E., Physiol Rev. 94, no. 2, 2014, p.329

$\overline{\text { Manuscript received: } 9.05 .2019}$ 